UOT 544.23

\title{
OPTIMAL CONDITIONS FOR GRAFT RADICAL COPOLYMERIZATION OF N-VINYLPIRROLIDON AND 4-VINYLPIRIDINE INTO CHITOSAN
}

\author{
Sh.Z. Tapdigov ${ }^{*}$, N.A. Zeynalov ${ }^{*}$, D.B. Tagiyev ${ }^{*}$, S.F. Safaraliyeva*, E.M. Gasimov", \\ M.Kh. Hasanova*, A.F. Nuraliyev ${ }^{ \pm}$, C.A. Sultanov ${ }^{*}$ \\ *Institute Catalysis and Inorganic Chemistry Azerbaijan National Academy of Sciences \\ H.Javid ave., 113, Baku AZ 1143, Azerbaijan Republic; e-mail: shamo.chem.az@gmail.com \\ \# Azerbaijan Medical University, Department of Surgery and Anaesthesiology \\ S.Vurgun, 167, Baku AZ 1022, Azerbaijan Republic; e-mail: elnurgasimov@rambler.ru \\ ${ }^{ \pm}$Institute of Physics National Academy of Sciences of Azerbaijan \\ H.Javid ave., 33, Baku AZ 1143, Azerbaijan Republic; e-mail: azhep@ physics.ab.az
}

Received 21.09.2018

In our study, new natural-synthetic, cross-linked copolymers were obtained by radical copolymerization of chitosan in the presence of 4-vinylpyridine and $\mathrm{N}$-vinylpyrrolidone. In order to cross-link 4vinylpyridine and $N$-vinylpyrrolidone to chitosan, the radical co-polymerization with azobisanobutyronitrile initiator were performed in the homogeneous phase in the presence of monomers. The combined effects of the major parameters to the cross-linked radical copolymerization were studied systematically. The cross-linking degree of the monomers to chitosan $(G)$ and dependence of crosslinking effectiveness (E) upon temperature, amount of chitosan, concentration of inisiator, solvent ratio, reaction time and concentration of monomers were studied. It revealed that $G=258 \%$ and $E=17-19 \%$ were max. at $60-70^{\circ} \mathrm{C}$, within $150 \mathrm{~min}$., in the cross-linked copolymerization of $0.35 \mathrm{~g}$ chitosan with 2.4 $\mathrm{mol} / \mathrm{l}$ of $\mathrm{N}$-vinylpyrrolidone and $0.2 \mathrm{~mol} / \mathrm{l}$ of 4-vinylpyridine in the presence of $75 \mathrm{ml} 2 \% \mathrm{CH}$ COOH as a solvent, and the estimated degree of homopolymerization at minimum $18-20 \%$. Through the use of ${ }^{1} \mathrm{H}$ NMR, FTIR, SEM, X-Ray and thermogravimetric analysis methods, the mechanism of radical crosslinked copolymerization was proposed on the basis of the cyclic breakdown of chitosan.

Keywords: chitosan; graft copolymer; $N$-vinylpyrrolidone; 4-vinylpyridine; radical polymerization

\section{INTRODUCTION}

The modification of cross-linked copolymerization of natural polymers is a perfect way of obtaining materials with new properties. This method involves the acquisition of a new generation of biopolymers by adding different functional groups to macromolecules. Thus, such natural synthetic cross-lnked materials are considered to be irreplaceable smart nanogels in medicine for drug delivery, genetic engineering, membrane conductivity, and tissues [1-4]. Chitosan from from deacetylation of Chitin is polyaminosaccharide which is residues of $\beta$ $(1,4)$-2-amino-2-deoxy- D-glucosamine and $\beta$ - $(1,4)$-N-acetyl D-glucosamine [5-8]. The free amine groups in chitosan provide its solubility in acidic solutions which forms positive charges on the polysaccharide macromolecule. Such positive charges allow chitosan and its modifications attract negativecharged drugs, proteins, bacteria and fungi [911]. It is possible to obtain different chitosan cross-linked polymers by radical polymerization of vinyl monomers in the homogeneous and heterogeneous phase in the presence of the chitosan as initiator. The radical polymerization reactions were analysed on various vinyl monomers such as, acrylnitrile, vinylacetate, methyl acrylate, methyl methacrylate, acrylic acid, acrylamide, vinylpyridines, vinylpyrrolidone, isopropyl acrylamide, etc. in the presence of different initiators [12-14]. Stimulating sysmens such as $\left(\mathrm{NH}_{4}\right) \mathrm{Ce}\left(\mathrm{NO}_{3}\right)_{6}, \mathrm{~K}_{2} \mathrm{~S}_{2} \mathrm{O}_{8},\left(\mathrm{NH}_{4}\right)_{2} \mathrm{~S}_{2} \mathrm{O}_{8}$, tributyl borane, Fenton's reagent $\left(\mathrm{Fe}^{2+}+\mathrm{H}_{2} \mathrm{O}_{2}\right)$, 2,2azobis (2-methylpropionnitrile), UV radiation, 
microwave radiation, etc. were used as initiator [15-16]. Also, the homogeneous crosslinking process of vinylpyrrolidone to chitosan along with the presence of potassium persulfate as redox initiator have been examined to reach $290 \%$ cross-linking. It found that the water solubility of the product from the cross-linking of vinylpyrrolidone to chitosan decreases. The same is observed in organic and inorganic solvents, as well as in diluted acitic solutions. The $\mathrm{HCl}$ solubility increased after formation of a complex of chitosan with copper ion. This is related to the formation of coordination bond with the amine group. In the present paper, the radical crosslinking copolymerization was performed concurrently with 4-vinylpyridine, Nvinylpyrrolidone and 2-azobisisobutyronitrile (AIBN) initiator to $150-300 \mathrm{kDa}$ molecular weight chitosan. The effect of temperature, the amount of chitosan, the concentration of initiator, the volume of the solvent, the reaction time and the effectiveness of the monomers' concentration were studied and the optimum value of the cross-linking were determined. The mechanism of cross-linking reaction was examined through the use of FTIR and ${ }^{1} \mathrm{H}$, NMR spectroscopy methods.

\section{EXPERIMENTAL}

\section{Samples}

Chitosan $M_{n}=35 \mathrm{kDa}$ (deacetylating degree 85-87\%), acetate acid (Glacial), ethanol (95\%), acetone (residue analysis, $\geq 99.9 \%$ ), diethyl ether (contains $1 \mathrm{ppm}$ BHT as inhibitor, anhydrous, $\geq 99.7 \%$ ) from SigmaAldrich. 4-vinylpyridine assay 95-96\%,(bp $62-65^{\circ} \mathrm{C} / 15 \mathrm{mmHg}$, ri 20/D 1.549) and $\mathrm{N}$ vinypyrrolidone assay $\geq 99 \% \quad$ (bp $\left.94{ }^{\circ} \mathrm{C} / 11 \mathrm{mmHg}, n 20 / \mathrm{D} 1.512\right)$ from Acros Organics had been distilled just before the use. Initiators of AIBN came to be analytical grade reagents from Fluka chemicals. All solvents came from Aldrich and were purified by distillation, according to the conventional methods.

\section{Grafting reactions, Swelling measurements and Quaternization.}

$1.5 \mathrm{~g}$ chitosan which is dried at $40-50{ }^{0} \mathrm{C}$ for 24 hours suspended in $150 \mathrm{ml}$ of $2 \%$ $\mathrm{CH}_{3} \mathrm{COOH}$. After 1-2 hours complete mixing, $2 \mathrm{~mL}$ of newly distilled monomers are added to the solution in $1: 1 \mathrm{~mol}$ ratio and continuously stirred for 30 minutes. The reaction medium is coupled to a $65^{\circ} \mathrm{C}$ water thermostat and the reaction performed in terms of inert gas- $\mathrm{N}_{2}$ environment in the $0.15 \mathrm{~mol} / \mathrm{l}$ AIBN concentration for 2 hours. Following an appropriate period, the solution is brought to $\mathrm{pH}=10-11$ by adding $1 \mathrm{M} \mathrm{KOH}$ after which the product precipitates. Cross-linked copolymer is filtered, washed 2-3 times with water, alcohol and acetone (to clean from poly-4-vinylpyridine, poly- $\mathrm{N}$-vinylpyrrolidone and monomers it is washed with diethyl ether for 2 days in Soxhlet). Cross-linked copolymer sample is dried to a constant weight at 40$50^{\circ} \mathrm{C}$. The yield is $78-86 \%$.

Swelling measurements were carried out in the distilled water, $\mathrm{pH}$ 6.5, acidic buffer $\mathrm{pH} 3.4$, and in the basic buffer at $\mathrm{pH}=10$ and at a room temperature. A well-known weight of the dry sample was placed into a tea-bag and immersed in the aqueous medium. In a while, the bag was taken out and hung for $5-10 \mathrm{~min}$ to eliminate excess unabsorbed water, and then weighed. The degree of swelling was calculated using the relation $\left(\mathrm{W}-\mathrm{W}_{0}\right) / \mathrm{W}_{0} * 100$ where $\mathrm{W}$ and $\mathrm{W}_{0}$ are the weight of the swollen and dry samples, respectively. Quaternization of chitosan and its grafted copolymers was achieved by heating the samples with dimethyl sulfate in the presence of $\mathrm{NaOH}$. 


\section{RESULTS AND DISCUSSION}

By varying the nature of the monomers and various parameters of cross-linking it is possible to change the hydrophobicity of the chitosan, which makes it possible to diversify with antibacterial properties.

Systematically, in terms of the cross-linking rate $\mathrm{G} \%$ 4-vinylpyridine and $\mathrm{N}$ vinylpyrrolidone to chitosan, the percentage of its use depending on a specific purpose. Another interesting change was the quaternization of cross-linked chitosan copolymer, which can be used as a material hopolymer $\left(\begin{array}{ll}\% & \mathrm{H}\end{array}\right)$ and the cross-linking efficiency E\% are investigated and determined according to the following expression:

$$
G \%=\frac{W_{2}-W_{1}}{W_{1}} \times 100, \quad H \%=\frac{W_{4}-W_{2}}{W_{3}} \times 100, \quad E \%=\frac{W_{2}-W_{1}}{W_{3}} \times 100,
$$

where $\mathrm{W}_{1}, \mathrm{~W}_{2}, \mathrm{~W}_{3}$ and $\mathrm{W}_{4}$ are the total amount of initial chitosan, the mass of crosslinked copolymer product after extraction, the total amount of $\mathrm{N}$-vinylpyrrolidone and 4vinylpyridine monomers, as well as the preextraction mass of cross-linked copolymer with grams, respectively.
The changes in the hydrophobicity of crosslinked copolymerization reaction are made depending on the molar ratio of monomer determined by using hydrophilic and hydrophobic monomers. Initially, cross-linked copolymerization reaction was determined depending on the amount of chitosan. Results are shown in Fig.1.

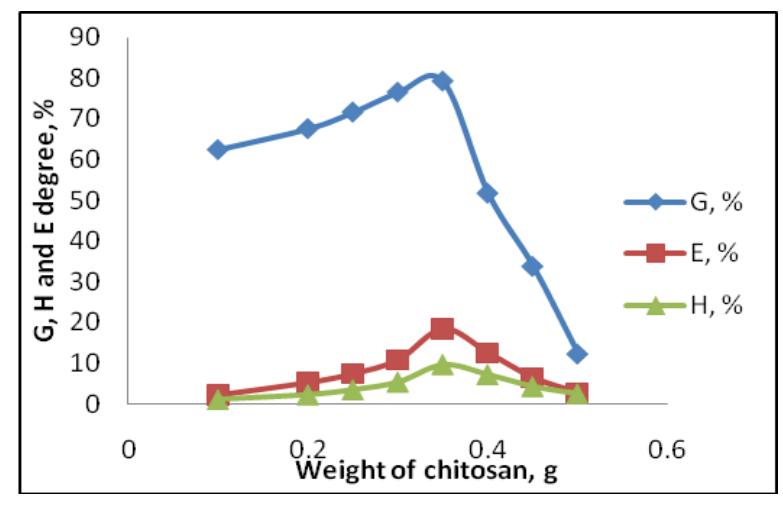

Fig. 1. The effect of chitosan on cross-linking. VP $=2 \mathrm{ml}, 4 \mathrm{VP}=2 \mathrm{ml}$, Solvent $=10 \mathrm{ml}, \mathrm{AIBN}=$ $0.01 \mathrm{~mol} / \mathrm{l}, \mathrm{T}=70^{0} \mathrm{C}, \mathrm{t}=120 \mathrm{~min}$.

As is seen from Fig.1, the degree of radical cross-linked copolymerization of chitosan was max. in the amount of $0.3-0.35$ g. High amounts of chitosan reduce the degree of cross-linking which is undesirable. We assign the objective to obtain a new characteristic copolymer together with monomer residues added to chitosan. Then, the copolymerization was carried out depending on the volume of another parameter solvent. Results are shown in Fig.2.

It was determined that the cross-linking is sufficient by $85-90 \%$ in $75 \mathrm{ml}$ of the solvent. Note that the rinse of the reaction medium reduces the interaction of active centers which indicates a decrease in the cross-linking effectivity. 


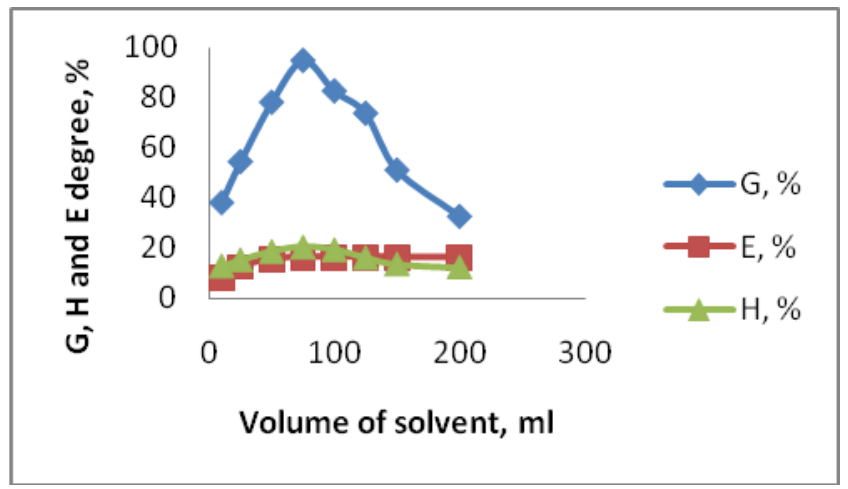

Fig. 2. Effect of the solution volume to the cross-linking. $\mathrm{m}_{\text {chitosan }}=0.35 \mathrm{~g}, \mathrm{VP}=2 \mathrm{ml}, 4 \mathrm{VP}=2 \mathrm{ml}$, $\mathrm{t}=120 \mathrm{~min}, \mathrm{~T}=70^{\circ} \mathrm{C}, \mathrm{AIBN}=0.01 \mathrm{~mol} / \mathrm{l}$.

Next, the impact of the initiator concentration process was examined, and the results which gives rise to active centers in the obtained are cited in Fig.3.

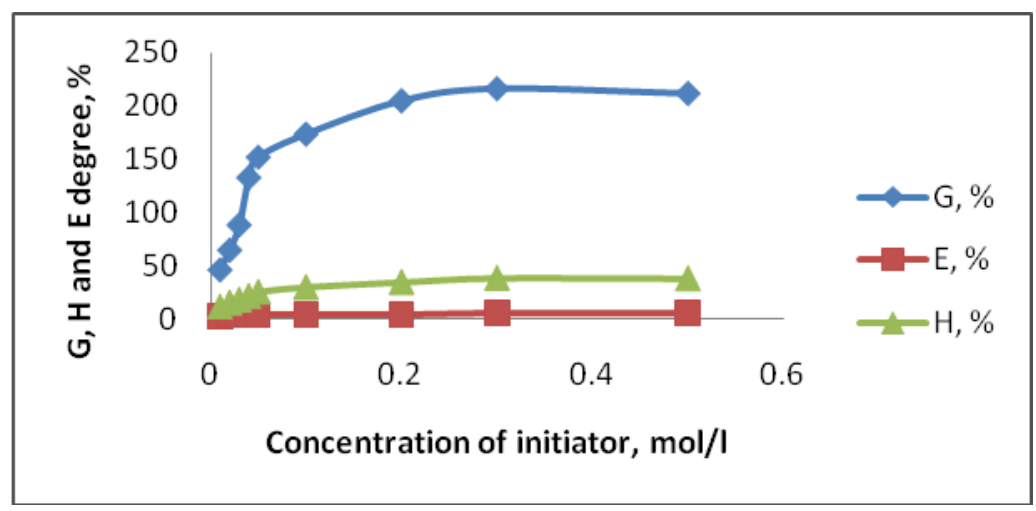

Fig. 3. Influence of incinerator concentration on cross-linking where $\mathrm{m}_{\text {chitosan }}=0.35 \mathrm{~g}, \mathrm{VP}=2 \mathrm{ml}$, $4 \mathrm{VP}=2 \mathrm{ml}, \mathrm{t}=120 \mathrm{~min}, \mathrm{~T}=70^{\circ} \mathrm{C}$, Solvent $=75 \mathrm{ml}$.

As is apparent from the diagram above, the radical cross-linking copolymerization reaction in $0.1-0.2 \mathrm{~mol} / \mathrm{l}$ concentrated solution of initiator is effective and characterized by more than 200\% cross-linking degree. This proves that the process is more active with the radical mechanism together with the majority of active centers which is due to the process acceleration. However, increased concentration of the initiator which leads the reaction towards the homopolymerization of more monomers is undesirable. From this point of view, using $0.15 \mathrm{~mol} / \mathrm{l}$ of the initiator can be optimally acceptable for copolymerization. The effect of the below parameter is the concentration of monomers (Fig.4) which led to more interesting results. It revealed that the hydrophobicity of crosslinked copolymer increases with the amount of $\mathrm{N}$-vinylpyrrolidone residues as compared to chitosan for a certain amount.

This can be explained by the increase of hydrogen, hydrophobic, electrostatic and intermolecular type interactions due to the increase of polyar groups in the cross-linked copolymer. The increased amount of hydrophobic monomer, 4-vinylpyridine leads to a certain degree of hydrophilicity and then declines sharply.

This is primarily caused by the easy ionization, as well as the polarization of functional groups due to the decrease between macromolecular interactions [17]. 


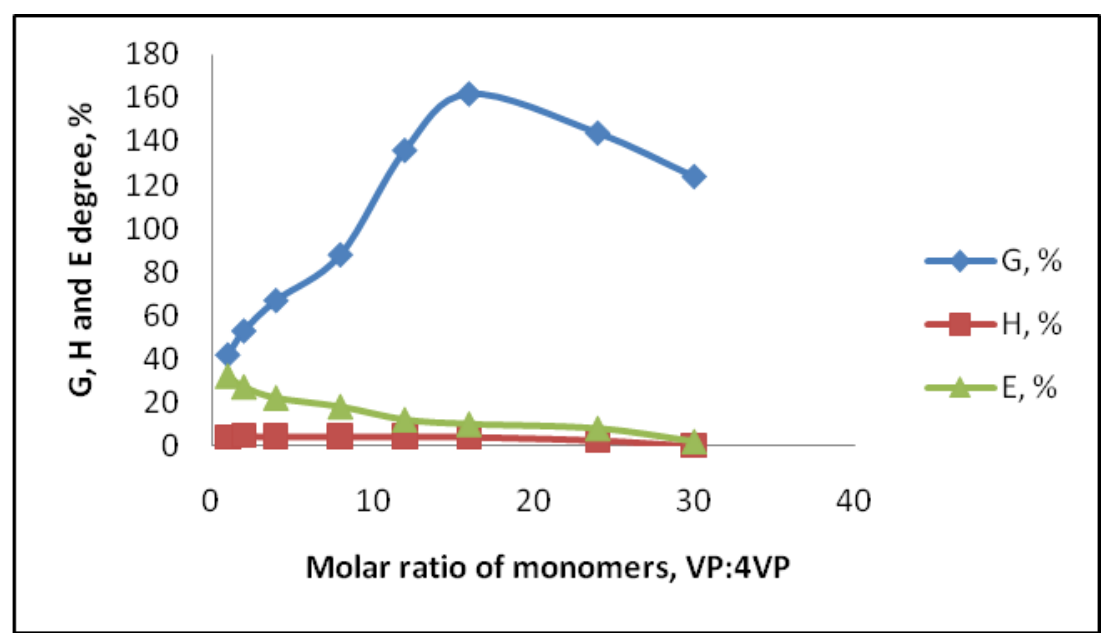

Fig. 4. Influence of monomers molar ratio to cross-linking $\mathrm{m}_{\text {chitosan }}=0.35 \mathrm{~g}, \mathrm{t}=120$ minutes, $\mathrm{T}=70^{\circ} \mathrm{C}, \mathrm{AIBN}=0.15 \mathrm{~mol} / \mathrm{l}$, Solvent $=75 \mathrm{ml}$.

The predominance of the subsequent 4- mixture of $0.2 \mathrm{~mol} / \mathrm{l} \mathrm{N}$-vinylpyrrolidone and vinylpyridine barks leads to greater $2.4 \mathrm{~mol} / \mathrm{l}$ 4-vinylpyridine. Subsequently, the hydrophobicity of cross-linked copolymer. time dependence of the process (Fig. 5) was This feature may limit its application as the studied by keeping monomers molar ratio most advantageous system based on the constant.

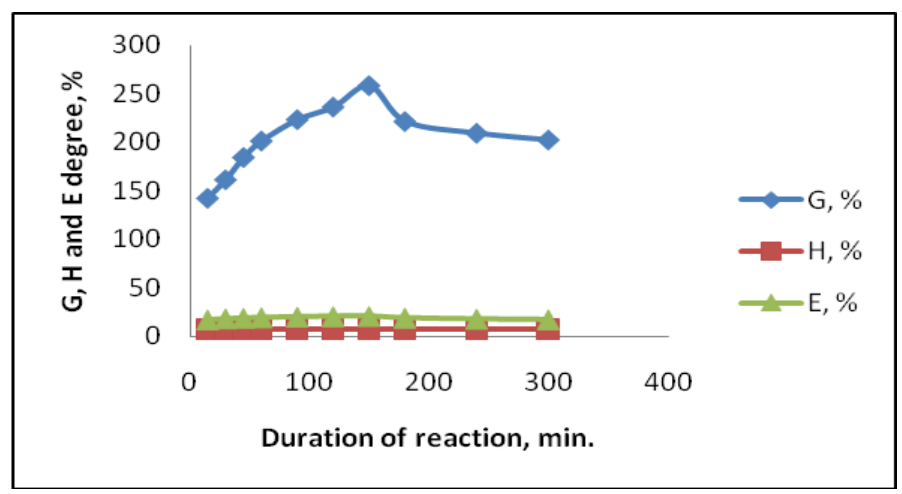

Fig.5. Influence of reaction time on cross-linking. $\mathrm{m}_{\text {chitosan }}=0.35 \mathrm{~g}, \mathrm{VP}=2.4 \mathrm{~mol} / \mathrm{l}, 4 \mathrm{VP}=0.2$ $\mathrm{mol} / \mathrm{l}, \mathrm{T}=70^{\circ} \mathrm{C}, \mathrm{AIBN}=0.15 \mathrm{~mol} / \mathrm{l}$, Solvent $=75 \mathrm{ml}$.

As is seen from Fig.5, the duration of the cross-linked copolymerization reaction is $\mathbf{1 5 0}$ minute. The additional reaction time leads to outer processes, including the recombination of obtained macroradicals and the fall in the cross-linking degree and effectiveness. Despite the stabilization of these parameters after 200 min., it may take 100-150 min. with max. cross-linking degree without applying additional energy. Finally, the temperature dependence of the radical cross-linking copolymerization reaction was investigated with the results shown in Fig.6.

As is evident from Fig.6, performing the radical cross-linking copolymerization reaction at the initiators' decomposition temperature improves the process effectivity and the high degree of cross-linking. Temperatures at $80-90^{\circ} \mathrm{C}$ and above are causing destructions and additional oxidation reactions which is naturally undesirable. 


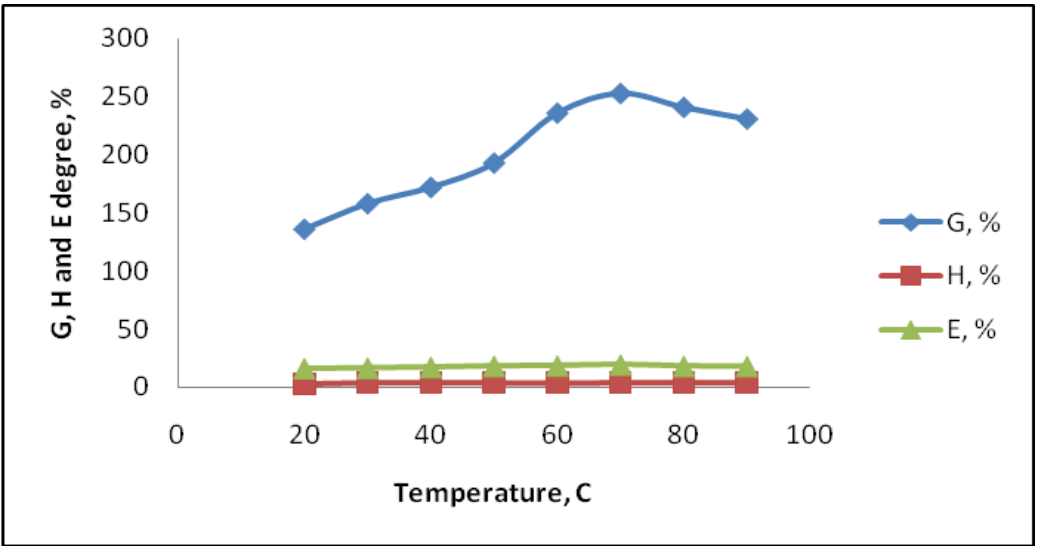

Fig. 6. Influence of temperature on cross-linking. $\mathrm{m}_{\text {chitosan }}=0.35 \mathrm{~g}, \mathrm{VP}=2.4 \mathrm{~mol} / \mathrm{l}, 4 \mathrm{VP}=0.2 \mathrm{~mol} / \mathrm{l}, \mathrm{t}=150$ min., AIBN=0.15 mol/l, Solvent $=75 \mathrm{ml}$.

Thus, a new method was developed for the cross-linking degree and efficacy, as well as the optimal homopolymerization conditions for the chitosan-block-co-poly-4vinylpyridine-co-poly-N-vinylpyridinecopoly-N-vinylpyrrolidone cross-linked copolymer. It revealed that at $60-70^{\circ} \mathrm{C}$ within 150 min., the cross-linking degree (258\%) and the effectivity (17-19\%) were max., while homopolymerization rate (18-20\%) was min. in the cross-linking copolymerization reaction in the presence of $75 \mathrm{ml}$ of $2 \% \mathrm{CH}_{3} \mathrm{COOH}$ solvent, $0.35 \mathrm{~g}$ of chitosan and $2.4 \mathrm{~mol} / \mathrm{l}$ of $\mathrm{N}$ vinylpyrrolidone and $0.2 \mathrm{~mol} / \mathrm{l}$ of 4 vinylpyridine.

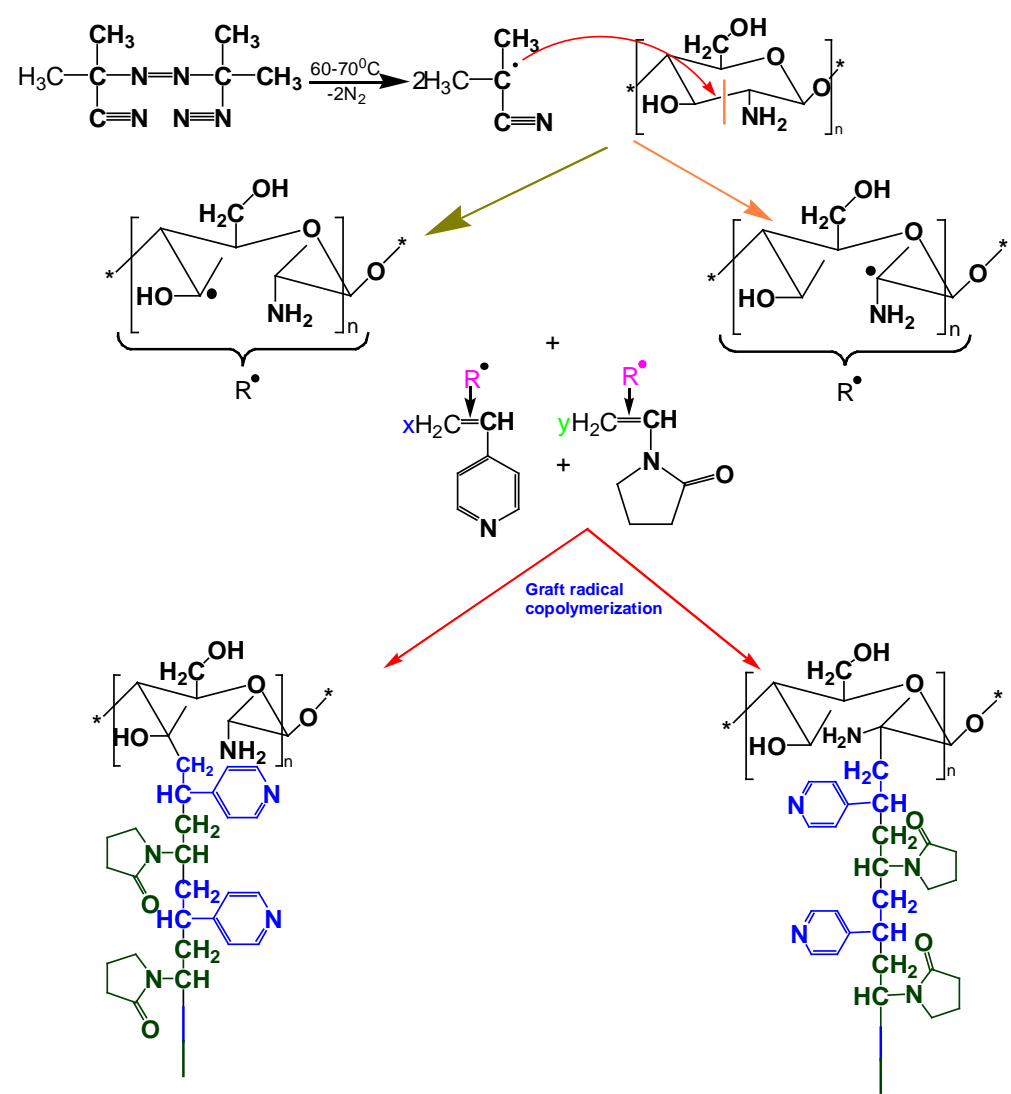

Fig. 7. A schematic description of the cross-linking copolymerization reaction of the 4-vinylpyridine and the $\mathrm{N}$-vinylpyrrolidone to chitosan. 
The oxidizing agent apparently attacks the chitosan backbone, and free radicals arise on the glucoside ring directly followed by the monomer attacking this center which leads to

The quaternization and swelling behaviour of chitosan cross-linked poly-4vinylpyridine-co-poly- $\mathrm{N}$-vinylpyrrolidone

The quaternization of cross-linked copolymer with dimethylsulfate in the alkaline environment was compared with chitosan. It was established that the increased degree of macromolecule polarization, either in chitosan and cross-linked copolymer, results in the growth of quaternization. This results in a 47$51 \%$ water diffusion. By adding max. calculated dimethyl sulfate to the content, the solubility of cross-linked copolymer rises as well. This tendency can be adjusted depending on the application area of the material. It found the formation of the PVP-P4VP side chain [18]. Two possible mechanisms in the grafting reaction could be illustrated in the following Fig.7.

that the swelling of cross-linked copolymer increases spontaneously within 5-6 hours and the saturation occurs in 9-10 hours. Also, it was discovered that the swelling rate heavily depends on the molar ratio of monomers in the composition. The optimal hydrophilicity was provided with $62 \%$ and $38 \%$ of the 4vinylpyridine and $\mathrm{N}$-vinylpyrrolidone residues in the composition, respectively. Swelling degree was checked in acidic, neutral and alkaline buffer environments which varied at $\mathrm{pH} 2.5>\mathrm{pH} 11>\mathrm{pH}$ 7-8. The results obtained indicate that the transportation of the drugs to appropriate environments turns out to be possible.

\section{Acknowledgements}

The work has been supported by the Science Development Foundation under the President of the Republic of Azerbaijan- Grant № EIF-KETPL-2-2015-1(25)-56/22/4

\section{REFERENCES}

1. Gupta K.C., Ravikumar M.N.V. J. Mater. Sci. Rev. Macromol. Chem.Phys. 2000, vol. 40, p. 273-308.

2. Peter M.G. in: A. Steinbuchel, R.H. Marchessault (Eds.). Biopolymers for Medical and Pharmaceutical Applications, WileyVCH, Weinheim, 2005, pp. 419-512.

3. Shemshadi R., Zeynalov N.A., Tapdiqov Sh.Z. et al. Removal of Cadmium (II) by Natural Absorbents. Kimya Problemleri - Chemical Problems. 2009, no. 3, pp. 586- 589. (In Azerbaijan).

4. Kozo O., Yui Y., Okuyama K. Three D structures of chitosan. Int. J. Biol. Macromol. 2004, vol.34, isses 1-2, pp. 1-8.

5. Winterowd J.G., Sandford P.A., in: A.M. Stephen (Ed.), Food Polysaccharides and Their Applications, Marcel Dekker, New York, 1995, pp. 441-462.
6. Einbu A., Naess S.N., Elgsaeter A., Varum K.M. Solution Properties of Chitin in Alkali

Biomacromolecules. 2004, vol. 5, no. 5, 2048-2054.

7. Tapdiqov Sh.Z., Zeynalov N.A., Ahmedov I.D., Nurullaev Q.Q., Mamedova S.Q. Analysis Of Trypsin Immobilization On Metal Complexes With Poly-N-Vinylpyrrolidone. Kimya Problemleri -Chemical Problems. 2010, no. 3, pp. 406-411. (In Azerbaijan).

8. Vincendon M., in: C.J. Brine, P.A. Sandford, J.P. Zikakis (Eds.),Advances in Chitin and Chitosan, Elsevier, London and New York,1992, pp. 556564.

9. Muzzarelli R.A.A., Guerrieri M., Goteri G., Muzzarelli C., Armen T., Ghiselli R., Cornelissen M. The biocompatibility of dibutyryl chitin in the context of wound dressings. Biomaterials. 2005, vol. 26, issue 29, pp. 5844-5854. 
10. Kakizaki M., Shoji T., Tsutsumi A., Hideshima T., in: R.A.A.Muzzarelli, C. Jeuniaux, G.W. Gooday (Eds.), Chitin in Nature andTechnology, Plenum Press, New York, 1986, pp. 398-402.

11. Bagheri-Khoulenjani S, Taghizadeh S.M., Mirzadeh H. An investigation on the short-term biodegradability of chitosan with various molecular weights and degrees of deacetylation. Carbohydr. Polym., 2009, vol. 78, pp. 773-778.

12. Vandevord, P.J., Matthew H.W.T., Desilva S.P., Mayton L, Wu B., Wooley P.H. Evaluation of the biocompatibility of a chitosan scaffold in mice. $J$. Biomed. Mater. Res., 2002, vol. 59, pp. 585-590.

13. Chatelet C., Damour O., Domard A. Influence of the degree of acetylation on some biological properties of chitosan films. Biomaterials, 2001, vol. 22, pp. 261-268.

14. Smith J. E. W., Dornish M. Effect of chitosan on epithelial cell tight junctions. Pharm. Res., 2004, vol.21, pp. 43-49.

15. Okamoto Y., Kawakami K., Miyatake K., Morimoto M., Shigemasa Y., Minami S. Analgesic effects of chitin and chitosan. Carbohydr. Polym., 2002, vol. 49, pp. 249-252.

16. Pourjavadi P., Mahdavinia G.R., Zohuriaan-Mehr M.J., Odian H. J ApplPolymSci. 2003, vol. 88, pp. 2048.

17. Yazdani-Pedram M., Lagos A., Campos N. Int J Polym Mater. 1992, vol. 18, pp. 25.

18. El-Tahlawy K., Huddson S.M., Graft copolymerization of hydroxyethyl methacrylate onto chitosan. Journal Appl. Polym. Sci., 2001, vol. 82, issue 3, pp. 683-702.

\title{
N-VINILPIRROLIDON VO 4-VINILPIRIDININ XITOZANA CALAQ RADIKKAL SOPOLIMERLOŞMOSININ OPTIMAL ŞӘRAITININ TODQIQI
}

\author{
S..Z. Tapdıqov ${ }^{*}$, N.A. Zeynalov ${ }^{*}$, D.B. Tağıyev ${ }^{*}$, S.F. Sofaroliyeva* , E.M. Qasımov ${ }^{\#}$, \\ A.F. Nuroliyev ${ }^{ \pm}$, C.A. Sultanov
}

*Azarbaycan Milli Elmlar Akademiyası, akad. M.Nağıyev ad. Kataliz və Qeyri-üzvi Kimya İnstitutu AZ1143,Bakı,H.Cavid pr.113, e-mail:shamo.chem.az@gmail.com

\# Azarbaycan Tibb Universiteti, Carrahlıq va Anesteziologiya Şöbasi AZ 1022 Bakl, S.Burğun küç.,167, e-mail: elnurgasimov@rambler.ru ${ }^{ \pm}$AMEA Fizika Institutu

AZ 1143 Bakl, H.Cavid küç., 117; e-mail: azhep@ physics.ab.az

Araşdırmada xitozanı 4-vinilpiridin vo N-vinilpirrolidon iştirakında radikal sopolimerlaşdirməklə yeni təbii-sintetik tərkibli calaq sopolimerlor materialı alınmışdır. Xitozana 4-vinilpiridin vo $\mathrm{N}$ vinilpirrolidonun calaq edilmasi üçün monomerlar iştirakında homogen fazada azobisizobutironitril inisiatoru ilo radikal birga calaq sopolimerlaşma reaksiyaları aparılmışdır. Calaq radikal sopolimerlaşmə prosesinə asas parametrlarin birga təsiri sistematik olaraq öyranilmişdir. Xitozana monomerlarin calaq olunma daracasi (G\%) va calaq effektliyinin (E\%) temperaturdan, xitozanın miqdarından, inisiatorun qatılı̆̆ından, halledicinin hacmindən, reaksiya müddatindan va monomerlarin qatıliğından asılı olaraq dayişmasi tadqiq edilmişdir. Müayyan olunmuşdur ki, 60-70 $0^{\circ}$-do, 150 daq. müddatinda, $75 \mathrm{ml} \mathrm{2 \% -li} \mathrm{CH}_{3} \mathrm{COOH}$ halledici, 0.35 qr xitozan ila $2.4 \mathrm{~mol} / \mathrm{l} \mathrm{N}$-vinilpirrolidon va $0.2 \mathrm{~mol} / \mathrm{l}$ 4-vinilpiridin iştirakinda calaq sopolimerlaşmə reaksiyasinda $G=258 \%$ va E=17-19\% max. olub, hamçinin homopolimerlaşmə daracasi $18-20 \%$ isa min. qiymat ila xarakteriza olunur. ${ }^{1} \mathrm{H}$ NMR, FTIR, SEM, X-Ray va termoqravimetrik analiz metodlarının totbiqi ilo radikal calaq sopolimerlaşməsi reaksiyasının asasən xitozandakı tsiklin qurılmast ila ehtimal olunan mexanizmi təklif olunmuşdur. 
Açar sözlər: xitozan, calaq-sopolimerlaşmə, N-vinilpirrolidon, 4-vinilpiridin, radikal polimerləşmə

\title{
ИССЛЕДОВАНИЕ ОПТИМАЛЬНЫХ УСЛОВИЙ ПРИВИТОЙ РАДИКАЛЬНОЙ СОПОЛИМЕРИЗАЦИИ N-ВИНИЛПИРРОЛИДОНА И 4-ВИНИЛПИРИДИНА НА ХИТОЗАН
}

\author{
ШІ.З. Тапдыгов ${ }^{*}$ Н.А. Зейналов", Д.Б. Тагиев ${ }^{*}$ Э.М. Гасымов", А.И. Маммедова", \\ А.Ф. Нуралиев ${ }^{ \pm}$Ч.А. Султанов" \\ "Институт Катализа и Неорганической химии имени академика М. Нагиева \\ Начиональной АН Азербайджана, \\ AZ1143 Баку, пр.Г.Джавида, 113, e-mail:shamo.chem.az@gmail.com \\ "Азербайджанский Медициский Университет, Отделение Хирургии и Анестезиологии \\ AZ 1022 Баку, ул. С.Вургуна 167, e-mail: elnurgasimov@rambler.ru \\ ${ }^{ \pm}$Институт Физики Национальной АН Азербайджана \\ AZ 1143 Баку, пр. Г.Джавида, 117; e-mail: azhep@ physics.ab.az
}

Радикальной сополимеризачией хитозана с участием 4-винилпиридина и N-винилпирролидона получены привитые сополимеры, содержащчие новые натурально-синтетические материальы. Для прививки 4-винилпиридина и N-винилпирролидона на хитозан проведена реакция совместной радикальной и привитой сополимеризаџии в присутствии мономера в гомогенной фазе, инициированной азобисизобутиронитрилом. Было изучено совместное действие основных параметров на прочесс привитой радикальной сополимеризаџии. Исследована зависимость степени прививки (G\%) мономеров на хитозан и эффективность прививки (Е\%) от температуры, количества хитозана, конщентрации инициатора, объема растворителя, времени реакции и кониентрации мономеров. Установлено, что при температуре 60-70 $\mathrm{C}$, продолжительности 150 мин., в присутствии растворителя - 75 мл 2\%-ной $\mathrm{CH}_{3} \mathrm{COOH}$, реакция сополимеризации 0.35 г хитозана с 2.4 моль/л $N$-винилпирролидоном и 0.2 моль/л 4винилпиридином характеризуется максимальными значениями степени прививки $G=258 \% u$ эффективности прививки $E=17-19 \%$ и минимальным значением степени гомополимеризации 18-20\%. Используя методы ${ }^{1} \mathrm{H}$ NMR, FTIR, SEM, X-Rау и термографический анализ, предложен предполагаемый механизм радикальной привитой реакции сополимеризации, характеризующчийся, в основном обрывом цикла хитозана.

Ключевые слова: хитозан, привитая сополимеризачия, N-винилпирролидон, 4-винилпиридин, радикальная полимеризащия 